\title{
Production Efficiency of Credit and Non- Credit Users of Poultry Egg Farmers in Ogun State, Nigeria:A Data Envelopment Analysis (DEA) Approach
}

\author{
Adewuyi S.A ${ }^{1}$,Folawole O.O ${ }^{1}{ }^{1}$ Biola Phillip ${ }^{2}$, E.O Fakoya ${ }^{3}$ \\ ${ }^{1}$ Department of Agricultural Economics and Farm ManagementFederal University of Agriculture, Abeokuta, \\ Ogun State Nigeria. \\ ${ }^{2}$ Department of Agricultural Extension and Rural DevelopmentFederal University of Agriculture, Abeokuta, \\ Ogun State Nigeria. \\ ${ }^{3}$ Department of EconomicsFederal University of Agriculture, Abeokuta, Ogun State Nigeria.
}

\begin{abstract}
This study analyzed the production efficiency of credit users and non-credit users among poultry egg farmers in Ogun state, Nigeria. The study made use of primary data via questionnaire administration. A multistage sampling technique was used to randomly select 120 farmers. Technical, allocative and economic efficiencies were assessed using Data Envelopment Analysis. Factors affecting Production Efficiencies of poultry farmers were determined by Tobit regression method. The result revealed the mean technical efficiency of $62.67 \%$, allocative efficiency of $71.05 \%$ and the overall economic efficiency of $42.16 \%$. This implied that poultry farmers could still increase their output by $37.33 \%$ or increase revenue by $28.95 \%$ showing that maximum output level can be achieved. The mean economic efficiency score of credit users was 0.42 while that of non-credit users was 0.39, this further showed that poultry farmers that used credit were more economically efficient than their counterparts who did not. Tobit regression analysis revealed that an increase in age ( $p<.05)$, educational status $(p<0.01)$, number of birds stocked $(p<0.01)$, credit amount $(p<0.05)$ will increase the likelihood of being technically and allocatively efficient while credit amount $(p<0.05)$ increased the likelihood of being economically efficient. However, access to extension agents $(p<0.1)$ by farmers, tends to make farmers economically inefficient. Age, farming experience, educational level, flock size, interest rate were factors affecting the production efficiency of credit and non-credit users of poultry egg farmers. Based on the results, appropriate policy on provision of credit should be made available for poultry egg farmers in order to increase their production efficiency.
\end{abstract}

Keywords: Agricultural credit, ,Allocative efficiency, Data envelopment analysis,Economic efficiency, Technical efficiency, tobit.

\section{Introduction}

In Nigeria, production of food has not increased at the rate that can meet the increasing population. While food production increases at the $2.5 \%$, food demand increases at $3.5 \%$ due to high rate of population growth of 2.83\% (CBN, 2004). The apparent disparity between the rate of food production and demand for food in Nigeria has led to increasing resort to food importation and high rates of increase in food prices. The demand and supply gap for animal protein intake is so high. The Food and Agricultural Organization recommends that the minimum intake of protein by an average person should be $65 \mathrm{gm}$ per day; of this, $36 \mathrm{gm}$ (i.e. $40 \%$ ) should come from animal sources. Nigeria is presently unable to meet this requirement. The animal protein consumption in Nigeria is less than $8 \mathrm{gm}$ per person per day, which is a far -fetched from the Food and Agricultural Organization minimum recommendation (Niang and Jubrin, 2001). The fall in poultry production could be attributed to inadequate infrastructure, inadequate finance among many other problems. Credit is considered the catalyst that activates other factors of production and make under used capacities functional for increased production. It also helps to determine the under utilization or over utilization of factor inputs. The study examines production efficiency of credit and non-credit users, and factors influencing credit use by farmers in the study area.

\section{Methodology}

The study was conducted in Ogun State, Southwest Nigeria. Ogun State was created on February $3^{\text {rd }}$, 1976 from the old western region. It lies within latitude $6^{\circ} \mathrm{N}$ and $8^{0} \mathrm{~N}$ and longitude $2^{0} \mathrm{E}$ and $15^{\circ} \mathrm{E}$. The population of males in Ogun State is 1, 847,243 while the female is 1, 880,855 and the overall total of Ogun State is 3, 728,098 according to National population census 2006 . The state is approximately $1.9 \%(16,762 \mathrm{~km})$ of Nigeria's $923,219 \mathrm{~km}$ land area; and located in the moderately hot, humid tropical climatic zone of south western Nigeria.It is made up of 20 Local Government Areas spread across the four main agricultural zones of the state- 
Egba, Ijebu, Remo, and Yewa/Awori. The poultry industry also provides employment opportunities for the populace, thereby serving as a source of income to the people in Ogun state.

The respondents were drawn using a multi-stage sampling process. At the first stage, purposive sampling technique was used to select two (2) Local Government Areas in each of the four (4) Agricultural Development Project (ADP) zones in the state where there are prevalent poultry farmers. This gave a total of 8 Local Government Areas (ObafemiOwode, Ipokia, Sagamu, Abeokuta South, Odeda, Ijebu North, Remo, Ikene). Stage two involved the use of snow ball sampling technique to select 15 poultry farmers from each of the 8 selected Local Government Areas in the four (4) ADP zones in Ogun state to give a total of 120 respondents. Primary data were collected by means of structured questionnaires from the sampled farm households. Data on socio-economic characteristics such as age, primary occupation, gender, years of schooling and family sized. Primary data were also collected on the farm inputs that is number of birds, drugs, feeds, family and hired labour and outputs data were obtained from the respondents.

\subsection{Estimation Technique}

The level of technical, allocative, and economic efficiencies estimation for poultry farmers follows Coelliet al(1998) using Data Envelopment Analysis (DEA) technique. DEA is a non-parametric approach and it doesn't require any functional for a given data. This method uses input and output data of decision making units to construct a piece-wise linear surface or the best-practice frontier for a given data. The input-Oriented DEA was used to estimate the production efficiency of the farmers.Technical Efficiency (TE) measured the ability of the firms to produce a given output using the smallest set of inputs. It is attained when the best available technology is used to achieve maximum output possible.

The technical efficiency was estimated by how much feasible output is maximized for a given level of input adopted from Yusuf and Malomo (2007), the mathematical linear programming below was used

$\operatorname{Max} \mathrm{Y}$

$\mathrm{Y}, \lambda_{1}, \ldots, \lambda_{\mathrm{k}}$

s.t

$$
\begin{aligned}
& \sum_{t=1}^{n} y i \quad \lambda i \geq \mathrm{Y}_{\mathrm{i}} . \\
& \sum_{t=1}^{n} x i \quad \lambda i \leq \mathrm{x}_{\mathrm{i}} \\
& \lambda_{\mathrm{i}} \geq 0
\end{aligned}
$$

$\mathrm{Y}_{\mathrm{i}}=$ the production output of each farm

$\mathrm{xi}_{\mathrm{i}}=$ the $\mathrm{nth}$ factor of production

$\lambda_{\mathrm{i}}=$ the weight assigned to each production unit.

$Y=\beta_{0}+\beta_{1} X_{1}+\beta_{2} X_{2}+\beta_{3} X_{3}+\beta_{4} X_{4}+\beta_{5} X_{5}+\beta_{6} X_{6}+\beta_{7} X_{7}+\beta_{8} X_{8}+\beta_{9} X_{9}+U_{i}$

$\mathrm{Y}=$ output (crates of egg)

$\mathrm{X}_{1}=$ Age in years

$\mathrm{X}_{2}=$ Gender $(1=$ Male, $0=$ Female $)$

$\mathrm{X}_{3}=$ Occupation ( 1 if poultry farming, $0=$ if otherwise, $)$

$\mathrm{X}_{4}=$ Extension visit in number

$\mathrm{X}_{5}=$ Credit amount in naira

$\mathrm{X}_{6}=$ Experience in years

$\mathrm{X}_{7}=$ Education in years

$\mathrm{X}_{8}=$ Labour cost in man per naira

$\mathrm{X}_{9}=$ Stock size in number

$\beta$ 's $=$ the unidentified parameter to be estimated.

$\mu \mathrm{i}=$ the error term.

Similarly, Chavaset al. (2005) also suggests that allocative efficiency perspective which is a measure of firm's ability to allocate input bundle or produce a given level of output in the cost minimizing way.

The overall economic efficiency which is defined as the capacity of a firm to produce a pre-determined quantity of output at minimum cost for a given level of technology (Farrel, 1957) this is computed as the product of the Technical Efficiency (TE) and Allocative Efficiency (AE) which gives the Economic Efficiency (EE). 


\subsection{Socio-economic characteristics of Poultry Egg Farmers. \\ III. Result And Discussion}

The study showedthat the mean age for credit users was 40 years while that of non-credit users was 43 years. It was observed that those between 41 and 50 years of age had the highest representatives with $43.2 \%$ and 43.3\% for both credit users and non-credit users among poultry farmers in Ogun State. This was in line with Yusuf and Malomo.(2007) who reported an average age of 44 years for poultry (egg) farmers in the same State. The study revealed that $86.4 \%$ of the respondents were male while $13.6 \%$ of the respondents were female poultry farmers for credit users, while $85.5 \%$ and $13.2 \%$ are female for non-credit users. The implication of the heavy participation of males in poultry production could be attributed to the rigor and stress which characterizes the poultry production business which many females might not be able to cope with. The field survey further showed that majority $(95.5 \%$ and $85.5 \%)$ of the credit users and non-credit users respectively were married and $4.5 \%$ and $14.5 \%$ of the of the credit users and non-credit users were singles.Majority (95\% and 76\%) of both credit users and non-credit users had post-secondary education which agrees with Ajibefun and Daramola (2000) who found out that education has a strong relationship with the level of production efficiency of poultry farmers as majority of the respondent had post-secondary education .

Table 1: Socio - economic characteristics of Poultry Farmers

\begin{tabular}{|c|c|c|c|c|c|c|}
\hline \multirow{2}{*}{ Variables } & \multicolumn{2}{|l|}{ Credit users } & \multicolumn{3}{|c|}{ Non-credit users } & \multirow[b]{2}{*}{ Mean } \\
\hline & Frequency & \%age & Mean & Frequency & $\%$ age & \\
\hline \multicolumn{7}{|l|}{ Age } \\
\hline Less than 30 & 8 & 18.2 & & 11 & 14.5 & \\
\hline $31-40$ & 15 & 34.1 & & 19 & 25.0 & \\
\hline $41-50$ & 19 & 43.2 & & 33 & 43.1 & \\
\hline $51-60$ & 2 & 4.5 & & 7 & 9.2 & \\
\hline 61 and Above & 0 & 0 & & 6 & 7.9 & \\
\hline \multirow{2}{*}{\multicolumn{7}{|c|}{ Gender }} \\
\hline & & & & & & \\
\hline Male & 38 & 86.4 & & 66 & 86.8 & \\
\hline Female & 6 & 13.6 & & 10 & 13.3 & \\
\hline \multirow{2}{*}{\multicolumn{7}{|c|}{ Marital Status }} \\
\hline & & & & & & \\
\hline Married & 42 & 95.5 & & 65 & 85.5 & \\
\hline Single & 2 & 4.5 & & 11 & 14.5 & \\
\hline Total & 44 & 100 & & 76 & 100 & \\
\hline \multicolumn{7}{|l|}{ Educational Status } \\
\hline Primary & 1 & 2.3 & & 5 & 6.6 & \\
\hline Secondary & 1 & 2.3 & & 6 & 7.9 & \\
\hline NCE/Diploma & 9 & 20.5 & & 6 & 7.9 & \\
\hline Bachelor Degree 27 & 61.4 & & & 63.3 & & \\
\hline Masters & 6 & 13.4 & & 10 & 13.2 & \\
\hline Total & 44 & 100 & & 76 & 100 & \\
\hline
\end{tabular}

Source: Field Survey, 2011

\subsubsection{Data Envelopment Analysis}

The technical, allocative and economic efficiencies of the credit users and non credit users among the poultry farmers were estimated using Data Envelopment Analysis (DEA) techniques, [ following Coelli (1998) and Chavas, et al. (2005) ].

The results obtained from the estimates of the set of linear equations indicated that Technical efficiency (TE) indices range from 10 to $100 \%$ for credit user with an average of $65.93 \%$. This means that if an average farmer in the sample was to achieve the $T E$ level of its most efficient counterpart, then an average farmer would be able to save $34.07 \%$ of its cost(i.e., 1 - [65.93/100]).

A similar calculation for the most technically inefficient farmer reveals cost savings of $90 \%$

(i.e., 1 - [10/100]). However, for non-credit users, the technical efficiency ranges from 12 to $100 \%$ with an average of $60.78 \%$. This means that if an average non-credit user in the sample was to achieve the TE level of its most efficient counterpart, then an average farmer could realize $39.22 \%$ cost savings (i.e., $1-60.78 / 100]$ ). A similar calculation for the most technically inefficient farmer reveals cost savings of $88 \%$ (i.e., 1 - [12/100]). The result of the technical efficiency further showed that credit users has $38.6 \%$ of its farmers in efficiency interval 0.81-1.00. 
The mean allocative efficiency of the poultry credit user in the study area was $71.63 \%$ with a minimum of $12.0 \%$ and a maximum of $100 \%$. This means that if an average farmer would achieve the allocative efficiency level of its most efficient counterpart, then the average farmer could save $28.37 \%$ cost savings (i.e., 1 [71.63/100]). A similar calculation for the most allocatively inefficient farmer reveals cost savings of $88 \%$ (i.e., 1 - [12.0/100]). While the mean allocative efficiency of non-credit users is $70.71 \%$ with a minimum of $0.08 \%$ and maximum of $100 \%$. This means that if the average farmer in the sample was to achieve the allocative efficiency level of its most efficient counterpart, then the average farmer could realize a $29.29 \%$ cost savings (i.e., 1 [70.71/100]). A similar calculation for the most allocatively inefficient farmer reveals cost savings of $92.0 \%$ (i.e., 1 - [8.0/100]).The result of the allocative efficiency further showed that credit users has $52.3 \%$ of its farmers in efficiency interval $0.81-1.00$

The combination of effect of technical and allocative factors showed that the average economic efficiency level. The result revealed that the average economic efficiency of the poultry credit user is only $47.85 \%$, with a minimum of $0.05 \%$ and a maximum of $100 \%$. These figures indicated that if an average farmer would reach the economic efficiency level of its most efficient counterpart, then an average farmer could experience a cost savings of $52.15 \%$ (i.e., 1 - [47.85/100]). The same computation for the least economically efficient farmer suggests a gain in economic efficiency of $95 \%$ (i.e., 1 - [5/100]). The non-credit users among the poultry farmer in the study area, have a mean economic efficiency of $38.87 \%$ with a minimum value of $4 \%$ and maximum value of $97 \%$. These figures also suggest that if the average non-credit users were to reach the Economic Efficiency level of its most efficient counterpart, then the average farmer could experience a cost savings of $61.13 \%$ (i.e., 1 - [38.87/100]). The same computation for the least economically efficient farmer suggests a gain in economic efficiency of $96 \%$ (i.e., 1 - [4/100]). The result of the economic efficiency further showed that credit users has $18.2 \%$ of its farmers in efficiency interval $0.81-1.00$ while only $9.2 \%$ of the noncredit users were also in this efficiency interval.

The $71.05 \%$ mean allocative efficiency found in this study was greater than $44 \%$ mean allocative efficiency reported by Bravo-Ureta and Antonio (1997) for a sample of peasant farmers in Dominican Republic. In addition, the average economic efficiency level of $42.16 \%$ reported in this study is higher than $31 \%$ average economic efficiency found in Bravo-Ureta and Pinheiro (1994) and 29\% reported by Hussain (1989).

Table 2: Data Envelopment Analysis for Production Efficiency for poultry egg farmers in Ogun State

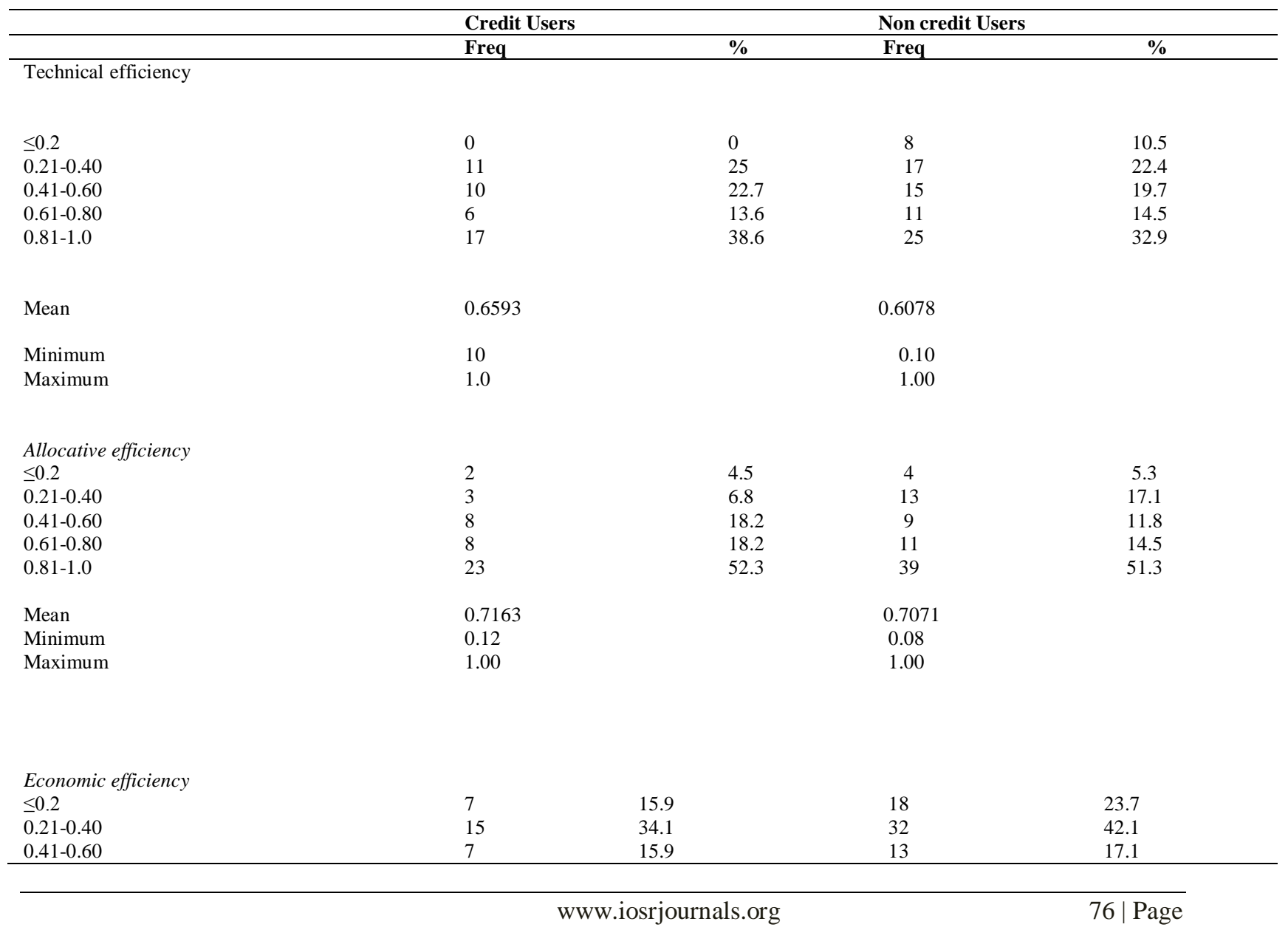


Production Efficiency Of Credit And Non-Credit Users Of Poultry Egg Farmers In Ogun State,

\begin{tabular}{lllc}
\hline $0.61-0.80$ & 7 & 15.9 & 6 \\
$0.81-1.0$ & 8 & 18.2 & 7 \\
Mean & 0.4785 & & 0.3887 \\
Minimum & 0.1 & 0.14 & 9.2 \\
Maximum & 1.00 & 1.00 & \\
\hline
\end{tabular}

\subsection{Tobitregerssion analysis} analysis.

Table 3 revealed factors affecting production efficiency of poultry farmers using Tobit regerssion

The result showed that occupation, educational level of the farmer and labour cost of the farmer were significant $(\mathrm{p}<0.01)$ while age was also significant $(\mathrm{p}<0.05)$. They all had a positive relationship with the technical efficiency of the farmer. This implies that most farmers were still active and technically efficient in owing to the fact that their educational level enhanced their ability in making use of information about production inputs.This agreed with the findings This agreed with the findings Onu et al (2000) who found that the more educated farmers are, the less technically inefficient they become. The level of education attained by a farmer not only increases his farm efficiency and productivity but also enhances his ability to understand and evaluate new production technologies (Obasi, 1991). However, experience of farmer was found to have a negative significant $(\mathrm{p}<1.0)$ relationship with technical efficiency, the more years poultry farmer gather as experience could also make them to latter be technically inefficient.

Extension contact was positively significant $(\mathrm{p}<0.1)$. This implies that the more extension agent visit farmers, allocative efficiency of poultry farmers also increases, flock size $(p<0.01)$ was also positively significant, this implies that as flock size increases, the allocative efficiency of poultry farmer increases. Age and experience of poultry farmers were negatively significant at $(\mathrm{p}<0.10)$, this implies that the older a farmer becomes, the more his efficiency drops, this is similar to the findings of Ojo and Ajibefun (2000) farmers with more experience are likely to be more conservative and are therefore less willing to adopt new practices, thus making them to be allocatively inefficient. Coellic and Batase (1998) also reported negative production elasticity with respect to farming experience for farmers in his village India. However, Education, and labour cost were negatively significant at $(\mathrm{p}<0.10)$ and $(\mathrm{p}<0.05)$ which tend to make them allocatively inefficient. This is contrary to the findings of Oleke and Isinika, (2011) who reported that, educational status, sex of the farm operator and use of credit positively influences the production efficiency of commercial egg producers.

Age $(p<0.01)$, Education $(p<0.01)$, and credit amount $(p<0.05)$ were positively significant respectively. This connotes that as age and education increase in years as well as the amount of credit used increase the economic efficiency of the poultry farmers increased. In addition labour cost, occupation, and flock size were positively significant at $(\mathrm{p}<0.05)$. This means that as more people choose poultry farming as occupation and more extension visit to the farmers with increase in their labour cost, their economic efficiency increases.

Table 3: Factors affecting production efficiency of poultry farmers in the study area

\begin{tabular}{|c|c|c|c|}
\hline & $\begin{array}{l}\text { Technical } \\
\text { Efficiency }\end{array}$ & $\begin{array}{l}\text { Allocative } \\
\text { Efficiency }\end{array}$ & $\begin{array}{l}\text { Economic } \\
\text { Efficiency }\end{array}$ \\
\hline Age & $\begin{array}{l}0.026759 * * \\
(2.5001)\end{array}$ & $\begin{array}{l}-0.0426741 * \\
(-1.72594)\end{array}$ & $\begin{array}{l}0.030161 * * * \\
(2.8646)\end{array}$ \\
\hline Gender & $\begin{array}{l}0.30810 \\
(1.2922)\end{array}$ & $\begin{array}{l}-0.05690 \\
(-0.24305)\end{array}$ & $\begin{array}{l}0.35758 \\
(1.5116)\end{array}$ \\
\hline Occupation & $\begin{array}{l}0.71193 * * * \\
(2.9364)\end{array}$ & $\begin{array}{l}0.15389 \\
(0.66933)\end{array}$ & $\begin{array}{l}0.48464 * * \\
(2.0848)\end{array}$ \\
\hline Extension visit & $\begin{array}{l}0.06897 \\
(0.95072)\end{array}$ & $\begin{array}{l}0.12742 * \\
(1.7954)\end{array}$ & $\begin{array}{l}0.16482 * * \\
(2.3113)\end{array}$ \\
\hline Credit amount & $\begin{array}{l}003864 * \\
(1.6056)\end{array}$ & $\begin{array}{l}0.000406 \\
(0.0172)\end{array}$ & $\begin{array}{l}0.056932 * * \\
(2.3689)\end{array}$ \\
\hline Experience & $\begin{array}{l}-0.0259^{*} \\
(-1.724)\end{array}$ & $\begin{array}{l}-0.0768^{*} \\
(-1.68185)\end{array}$ & $\begin{array}{l}-0.022978 \\
(-1.5357)\end{array}$ \\
\hline Education & $\begin{array}{l}0.0868^{* * * *} \\
(3.225)\end{array}$ & $\begin{array}{l}-.04809 * \\
(-1.8619)\end{array}$ & $\begin{array}{l}0.066862 * * * \\
(2.5713)\end{array}$ \\
\hline Labour cost & $\begin{array}{l}0.0001139 * * * \\
(3.2590)\end{array}$ & $\begin{array}{l}-0.008377 * * \\
(-2.4415)\end{array}$ & $\begin{array}{l}0.0016084 * * * \\
(4.5713)\end{array}$ \\
\hline Flock size & $\begin{array}{l}0.001288 * \\
(1.7705)\end{array}$ & $\begin{array}{l}0.007170 \text { **** } \\
(2.6917)\end{array}$ & $\begin{array}{l}0.0019328 * * \\
(2.3756)\end{array}$ \\
\hline Constant & -2.3855 & 5.1783 & -2.9894 \\
\hline $\begin{array}{l}\text { Likelihood function } \\
\text { Mean square error } \\
\text { Experience }\end{array}$ & $\begin{array}{l}33.164717 \\
-0.022 \\
-0.0259 * \\
(-1.724)\end{array}$ & $\begin{array}{l}23.712 \\
0.03719 \\
-0.0768^{*} \\
(-1.68185)\end{array}$ & $\begin{array}{l}75.602814 \\
0.15438 \\
-0.022978 \\
(-1.5357)\end{array}$ \\
\hline
\end{tabular}

Figures in parenthesis are t-ratios

*: significant at 10\%, **: significant at $5 \%$, ***significant at $1 \%$. 


\section{Source: Field survey, 2011.}

\section{Conclusion and Recommendation}

The study found that the cogent factors that affect the production efficiency of the respondents were educational level attained, age, gender, years of poultry farming experience, credit amount, and the number of birds stocked among other factors.

As a result of the information provided above, this study can therefore ascertain that the production efficiency of poultry egg farmers would be higher when necessary inputs that would prove their production efficiently are put in place.

\section{Recommendations}

Based on findings of this study, the following recommendations were advanced towards alleviating the problems being encountered by poultry farmers and increasing their production efficiency:

1. Stakeholders should organize agricultural programmes that cut across different age categories in order to allow evenly participation in poultry production.

2. Policy should be adjusted to improve the provision of agriculturalcredit to poultry egg farmers in the State.

3. Farmers should aim at increasing their flock size as increase in flock size helps increasing efficiency.

Annual Report:

\section{References}

[1]. Central Bank of Nigeria, 2004. Annual Report and statement of Accounts.CBN Publications.

Journal Papers:

[2]. Niang, T. and S. Jubrin, 2001. Quarterly Newsletter of the Nigeria Agriculture Question and Answer Service Vol.1 No. 3.

[3]. Coelli, T.J. Rao, D.S.P, Battase, G.E 1998. An Introduction to Efficiency and Productivity Analysis, Kluwer Academic Publishers, Boston.

[4]. Yusuf and Malomo 2007. “ Technical Efficiency of poultry egg production in Ogun State. International journal of Poultry Science 6 (9): 622-629.

Theses:

[5]. Hussain, Syed S. 1989: “Analysis of Economic Efficiency in Northern Pakistan: Estimation, Causes and Policy Implications.” Ph.D. diss., University of Illinois.

Journal Paper :

[6]. Farrel, J.M., 1957: The Measurement of Productive Efficiency. Journal of Royal Statistics 506 vol.120 part III Pp 253-290.

[7]. Bravo-Ureta, B.E., and Pinheiro A.O. 1997. Technical, Economic, and Allocative Efficiency in Peasant Farming: Evidence from the Dominican Republic. The Developing Economies, Vol.35 (1): 48-67.

[8]. Bravo-Ureta, B.E., and. Evenson. 1994. "Efficiency in Agricultural Production: The Case of PeasantFarmers in Eastern Paraguay." Agricultural Economics 10(1): 27-37.

Theses:

[9]. Hussain, Syed S. 1989: “Analysis of Economic Efficiency in Northern Pakistan: Estimation, Causes and Policy Implications.” Ph.D. diss., University of Illinois.

[10]. Onu, J.I., Amaza, P.S and Okunmadewa F. Y. 2000. Determinant of Cotton Production and Economic Efficiency in Nigeria.African Journal of Business and Economic research 112: 34-40.

[11]. Obasi, P. C. (1991) "Resource use Efficiency in Food Crop Production: A case of the Owerri Agricultural Zone of Imo State". MSc. Thesis University of Ibadan, Ibadan, Nigeria.

[12]. Journal Paper

[13]. Ojo S. O; and Ajibefun, A. A; 2000."Effect of Training on Labour Productivity and Efficiency in oil palm Production in Ondo State, Nigeria" Journal of sustainable Agriculture and Environment. 2: 275-279.

[14]. Oleke, J.M and Isinika, A.C 2011. 'Assessing the Technical Efficiency of Commercial Egg Production in Tanzania for Improved Livelihoods.Journal of Development and Agricultural Economics. Vol. 3(8) . 